\title{
Unravelling Seascape Patterns of Cryptic Life Stages: Non-Reef Habitat Use in Juvenile Parrotfishes
}

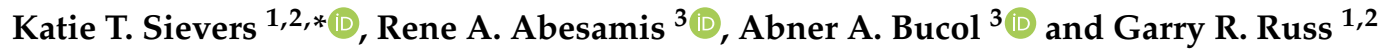 \\ 1 College of Science and Engineering, James Cook University, Townsville, QLD 4811, Australia; \\ garry.russ@jcu.edu.au \\ 2 ARC Centre of Excellence for Coral Reef Studies, James Cook University, Townsville, QLD 4811, Australia \\ 3 Silliman University Angelo King Center for Research and Environmental Management, Silliman University, \\ Dumaguete City 6200, Philippines; rene.abesamis@gmail.com (R.A.A.); abnerbucol2013@gmail.com (A.A.B.) \\ * Correspondence: katie.sievers@my.jcu.edu.au
}

Received: 10 August 2020; Accepted: 28 September 2020; Published: 30 September 2020

\begin{abstract}
Juvenile fish often use alternative habitats distinct from their adult phases. Parrotfishes are an integral group of coral reef fish assemblages, are targeted in fisheries, are sensitive to reef disturbances, and have been documented as multiple-habitat users. Considering the abundance of research conducted on parrotfishes, very little is known about their juvenile ecology at the species level due to their cryptic and variable coloration patterns. We collected juvenile parrotfishes in non-reef habitats (macroalgal beds, seagrass beds, and lagoons) in the Philippines and used DNA analysis to determine species composition. The results were then compared with data on adult parrotfish abundance from underwater visual census (UVC) surveys in coral reef and non-reef habitats. Collections identified 15 species of juvenile parrotfishes in non-reef habitats, and of these, 10 were also recorded in UVCs as adults. Informed by adult surveys, $42 \%$ of the 19 parrotfish species observed as adults were classified as multi-habitat users based on their presence in coral reef and non-reef habitats. When accounting for the occurrence of species as juveniles in non-reef habitats, $93 \%$ of the species collected as juveniles would be considered multi-habitat users. Species identified as juveniles in non-reef habitats comprised $50 \%$ of the average adult parrotfish density on coral reefs and $58-94 \%$ in non-reef habitats. The species richness of juveniles in non-reef habitats was greater than that of adults occupying the same habitats, and the most common adult species observed in UVCs was not collected as juveniles in non-reef habitats. Finally, UVC suggested that $97 \%$ of juvenile parrotfish $<10-\mathrm{cm}$ total length was present in non-reef habitats compared to coral reefs. These results provide further evidence for ontogenetic movement across habitat boundaries for parrotfish species in a diverse and highly connected tropical seascape. This is one of the few studies to quantify links between nursery and adult habitat in parrotfishes, highlighting the importance of including non-reef habitats in ecological studies of an iconic group of coral reef fish.
\end{abstract}

Keywords: juveniles; ontogeny; seascape; parrotfish; coral reefs; nursery habitat

\section{Introduction}

Juvenile fish often use alternative habitats distinct from their adult phases. This strategy is assumed to increase juvenile survival, which contributes to adult populations. These alternative habitats are defined as nursery habitats [1-4]. In tropical seascapes, juvenile fish often use non-coral reef habitats such as seagrass, macroalgal beds, lagoons, and mangroves [3,5-8]. Non-reef habitats can have reduced predation levels compared to coral reefs but often at the cost of reduced growth rates $[9,10]$. This fitness trade-off is a key element driving nursery habitat use, where juveniles use habitats adjacent to coral reefs before moving to coral reefs as adults [11], otherwise known as ontogenetic habitat 
migrations. For ontogenetic shifts to occur, the benefit of the unidirectional shift must outweigh the risk associated with the migration or change [12-14].

Ontogenetic shifts often occur in conjunction with morphological and size changes. For example, juvenile parrotfish less than $10 \mathrm{~cm}$ in total length (TL) feed predominately on small crustaceans [15] and, then, switch to scraping or excavating coral and hard substrata to consume endolithic and epiphytic protein-rich microorganisms as adults [16]. This dietary shift is facilitated by morphological changes of the mouth, jaw, and intestine [17], allowing individuals to shift from carnivory to "herbivory". Morphological changes can thus influence habitat use patterns, where ontogenetic movement is driven by resource needs. Ontogeny also displays shifts in mobility or home range sizes. Fish are more likely to move greater distances [18] or to have increased home ranges $[19,20]$ as body size increases and as an individual's resource needs change. Ontogenetic shifts, especially ones driven by changes in habitat needs, can be spatially linked, as physical migrations may occur across habitat boundaries.

The spatial arrangement of habitats within a seascape can modify ontogenetic processes. While resource requirements are fundamental to driving ontogenetic habitat use, the strength of the connection between nursery habitats and coral reefs is contingent on the spatial arrangement of the seascape as well as on the individual species' movement capabilities. Firstly, non-reef habitats must be present. Secondly, the spatial proximity of habitats in a seascape must be great enough that fishes can reasonably move between and among different habitats. The use of non-reef habitats is not necessarily obligatory and is more likely opportunistic, whereby fishes exploit non-reef habitats when available [21,22]. Nagelkerken et al. [23] showed that French grunts on coral reefs had dietary signatures from seagrass habitats only when seagrasses were close to coral reefs. In a small island system in Mozambique, Berkström et al. [24] demonstrated that $8 \mathrm{~km}$ or more of separation between seagrass nursery habitats and coral reefs resulted in a steep reduction in fishes on coral reefs that use seagrass nursery habitat. Individuals may be deterred by natural barriers such as sand or deep trenches [25,26], and the link between nursery and adult habitats can only occur if species are capable of migrating across habitat boundaries. The linkages between non-reef habitats and coral reef habitats are therefore strongly dependent on the spatial arrangement of the habitat in a seascape. However, the flexibility in the use of non-reef habitats as nurseries has not been explored in detail. It is critical for us to understand the scope and degree to which species use non-reef habitats as nurseries to gain a more accurate understanding of habitat-use patterns for fishes across multiple life stages.

Seagrass beds, macroalgal beds, mangroves and lagoons are all considered potential nursery habitats in tropical seascapes for a wide range of fish species [4,5,21,27-29]. Macroalgal beds, often dominated by Sargassum, have recently been confirmed as important habitat for the juveniles of a substantial number of near-shore fish species [8]. Research in macroalgal beds at the seascape level is limited, and we lack a complete understanding of the strength of connections between macroalgal beds and coral reefs. Furthermore, the list of species identified in non-reef habitats that may have previously been considered "coral reef" species is growing [30]. Multi-habitat use patterns exist across a diverse group of fish families [28,31-33], but only within the last decade has a more holistic approach been applied to exploring species patterns across multiple habitats.

Parrotfishes (Family: Labridae, subfamily Scarinae) are abundant, incredibly diverse, highly exploited by fisheries, contribute to key ecological processes on coral reefs, and are thus extremely well studied [34-36]. They are well documented as multiple habitat users, often recorded in adjacent non-reef habitats [30,37-39]. However, parrotfishes are notoriously difficult to identify to the species level, with a wide range of coloration patterns that change with body size and sex. Initial phase sub-adults and terminal phase adults are fairly accurately identified, but identifying the juvenile phases of parrotfish to the species level is very difficult due to their varied and often cryptic coloration patterns [40]. Most research describes parrotfish juveniles as only "Scarus spp." when exploring juvenile habitat patterns [41-44], but see [45]. Typical studies may be dealing with 2-3 dozen species of parrotfishes, especially in the Indo-Pacific. Because of this, we lack the fundamental resolution to appropriately describe nursery use patterns in parrotfishes, inhibiting our ability to directly link 
juvenile and adult habitat use at the species level. This is especially concerning for a taxonomic group as well studied as parrotfishes.

Here, we used DNA analysis to determine the species composition of juvenile parrotfishes in non-reef habitats. We then compared the data with visual survey data of adult parrotfishes in coral reef and non-reef habitats to compare and contrast juvenile and adult habitat use patterns. DNA analysis allows for the identification of small $(<10 \mathrm{~cm} \mathrm{TL})$ juvenile fishes to the species level across the family [46]. Our objectives are to explore potential nursery habitat use of parrotfish juveniles, to identify which non-reef habitats are important, and to determine which parrotfish species potentially undergo ontogenetic habitat shifts between juvenile and adult phases. With the identification of juvenile parrotfish using DNA, we can begin to explicitly describe diverse habitat use patterns for an important and highly diverse group of reef fish.

\section{Materials and Methods}

\subsection{Study Site}

Research was conducted on the southwestern side of Siquijor Island (Figure 1), in the Visayan region of the Philippines. This area is characterized by a mosaic of sub-tidal and inter-tidal benthic habitats extending up to $1 \mathrm{~km}$ off the coastline. Non-reef habitats include lagoons, macroalgal beds, seagrass beds, and mangrove stands adjacent to fringing coral reef habitat. Lagoons on Siquijor are characterized by deeper areas that are predominately sand with patches of seagrass and small corals. Macroalgal beds are composed of Sargassum species when seasonally present and with understory red, brown, and green algae that dominates when Sargassum senesces. Seagrass beds are characterized by a diverse set of seagrasses from the genera Cymodocea, Halodule, Thalassodendron, Enhalus, Halophila, and Thalassia with patchy sand, coral, and macroalgae interspersed. Mangrove habitats are patchily distributed across the island and are mainly composed of Rhizophora spp. that were planted in the early 1990s [47], with some remaining natural stands of Sonneratia and Avicennia spp. This region in the Philippines was selected specifically because it has extensive seagrass and macroalgal beds very close to coral reefs. It therefore presents an opportunity to evaluate multi-habitat use patterns in a seascape that may facilitate ontogenetic movement between different habitats.

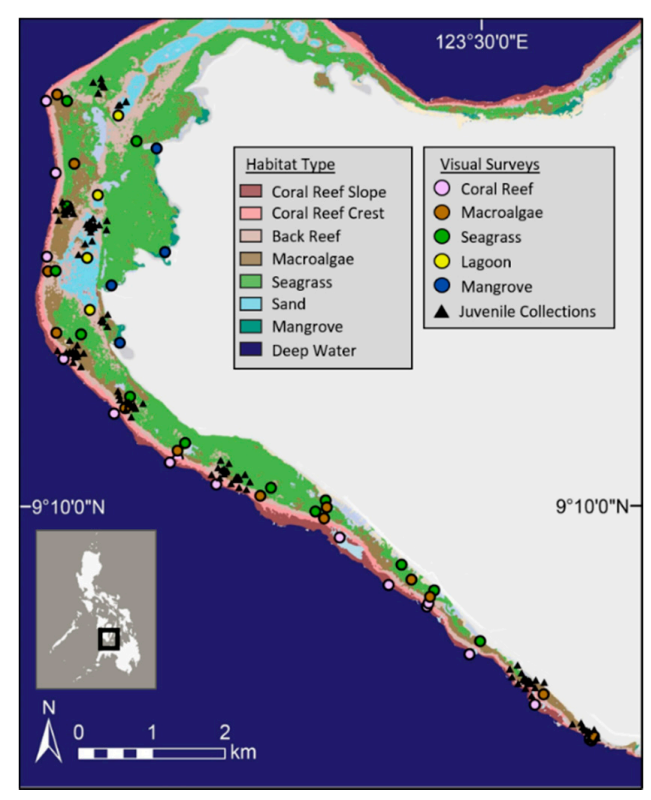

Figure 1. Map of the western section of Siquijor Island in the Philippines: coloured circles mark the centroid of the sites surveyed within each habitat. Black triangles mark the collection locations for juvenile parrotfishes. 


\subsection{Fish Surveys and Fish Collections}

Fish surveys were conducted in April 2015 at 52 sites distributed across five habitat types (coral reef, seagrass bed, macroalgal bed, lagoon, and mangroves) on the south western side of Siquijor Island (Figure 1). Underwater visual census (UVC) was conducted using replicate circular plots with a diameter of $10 \mathrm{~m}\left(78.5-\mathrm{m}^{2}\right)$ in all sites except those in mangroves. The minimum distance between sites was $50 \mathrm{~m}$. Each circular plot was surveyed in one complete rotation, being careful not to miss faster moving and smaller species. Sites in mangroves were surveyed using replicate belt transects $20 \mathrm{~m}$ in length and $5 \mathrm{~m}$ wide. Total area differed between habitat types, and thus, the number replicate plots was determined by available habitat. The numbers of replicate plots for coral reef, macroalgal bed, seagrass bed, lagoon, and mangrove were $96,60,44,16$, and 15, respectively. Fishes were identified to the species level when possible, and their total lengths (TLs) were estimated to the nearest centimetre and classified as either adult or juvenile. Because smaller parrotfishes are extremely difficult to correctly identify at the species level during surveys, parrotfish individuals under 10-cm TL were classified as juvenile and identified as a generic "Scarus spp." for the analysis. A number of parrotfish were confidently identified to the species level as juveniles during surveys due to their distinct juvenile coloration patterns [40]. Namely, Cetoscarus ocellatus, Chlorurus microrhinos, Scarus dimidiatus, and Scarus niger. The data analysis also explored treating these species separately from the generic "Scarus spp." analysis.

Habitat-use patterns for adult parrotfish were classified based on observations from circular plot surveys. If an adult parrotfish species was observed in the coral reef habitat only, they were classified as coral reef exclusive. If a species was observed in any non-reef habitat (seagrass beds, macroalgae, and/or lagoon) but not coral reefs, they were classified as non-reef habitat users. If species were observed in any one of the non-reef habitats as well as coral reef habitat, they were classified as multi-habitat users.

To examine which species of parrotfishes were using non-reef habitats as juveniles, small juvenile parrotfishes were collected in March 2018. Collections were focused in seagrass beds, macroalgal beds, and lagoon areas, and GPS locations were recorded for all collections (Figure 1). Parrotfishes less than $10-\mathrm{cm}$ TL were targeted by snorkelers using small hand nets and barrier nets. Once captured, fish were immediately transported to the boat and put on an ice slurry. Fish were stored in a $-20^{\circ} \mathrm{C}$ freezer in a laboratory in Dumaguete City, Negros Oriental, awaiting further processing, which was conducted in July 2018. For DNA analysis, caudal fin clips were taken from frozen fish samples and stored in 5-mL vials containing 95\% ethanol. Total length (TL) and weight (g) were recorded for each fish. Vials were then shipped to James Cook University in Townsville, Australia for the remaining laboratory analysis.

Species were collected under the JCU ethics permit A2536. Collections were authorized by Gratuitous Permit 0132-17, Department of Agriculture, Philippines and prior informed consent from Siquijor and San Juan municipalities. Utilization of samples was governed by a Materials Transfer Agreement between Silliman University and James Cook University.

\subsection{DNA Sequencing}

DNA extraction from caudal fin clips was performed with the Isolate II kit (Bioline) for genomic mitochondrial DNA following the manufacturer's instructions. The cytochrome oxidase subunit I (COI) gene for fish was selected and amplified using the COI primers identified in Ward et al. [48] for FishF2-5'TCGACTAATCATAAAGATATCGGCAC3' , and FishR2-5' ACTTCAG GGTGACCGAAGAATCAGAA3'. PCR amplification was performed for a total volume of $25 \mu \mathrm{L}$, with $13.625 \mu \mathrm{L}$ ultrapure water, $5 \mu \mathrm{L}$ GoTaq $5 \times$ PCR buffer, $2.5 \mu \mathrm{L}$ dNTPs $(10 \mathrm{mM}), 2.5 \mu \mathrm{L} \mathrm{MgCl} 2$ $(25 \mathrm{mM}), 0.125 \mu \mathrm{L}$ Taq DNA polymerase, $0.125 \mu \mathrm{L}$ each primer $(100 \mu \mathrm{M})$, and $1 \mu \mathrm{L}$ DNA template. Fragments were amplified using the thermal regime detailed in Ward et al. [48] for two minutes at $95^{\circ} \mathrm{C}$; then 35 cycles of $30 \mathrm{~s}$ at $94{ }^{\circ} \mathrm{C}, 30 \mathrm{~s}$ at $54{ }^{\circ} \mathrm{C}, 60 \mathrm{~s}$ at $72{ }^{\circ} \mathrm{C}$, and $10 \mathrm{~min}$ at $72{ }^{\circ} \mathrm{C}$; and then held at $4{ }^{\circ} \mathrm{C}$. The PCR products were visualized and inspected with $0.8 \%$ agarose gel with gel green, before 
shipment for sequencing. Forward and reverse gene fragments were sequenced at Macrogen Inc. facilities in Seoul, Korea.

\subsection{Analysis of Sequences}

Sequences were evaluated and edited using the software Geneious Prime (v.2020.1). Reverse and forward sequence ends were manually trimmed, and pairwise alignments were used to create a consensus sequence. Pairwise identity, number of ambiguities, and quality scores were evaluated and inspected within Geneious software to identify any potential sequence issues. When consensus alignment sequences were of poor quality, cleaned forward or reverse sequences would be used for a Basic Local Alignment Search Tool (BLAST) on GenBank (https://www.ncbi.nlm.nih.gov/genbank/) in addition to consensus sequences. The top GenBank hits for each BLAST were scrupulously checked. Additionally, all sequences were run against the Barcode of Life Data (BOLD) Systems (https://www.boldsystems.org/) website, and results from both GenBank and BOLD were carefully examined and assigned a confidence level for accuracy of species identification [49]. Parrotfish can be difficult to identify correctly based on morphology and colour of their terminal phases, and further assessments of top GenBank and BOLD hits were necessary as misidentification of species in this subfamily were found to be common. Considerations to select the most accurate species identification are listed as follows: quality of DNA sequences (quality score, alignment score, and ambiguities), percent similarity between sequenced DNA and databank sequence, databank reference information accessibility and/or a peer reviewed publication, photo associated with databank reference collection, details of collection (location, collector, and associated tags), and consistency of species identification for top hits. Based on these criteria, confidence measures of high, medium, and low were given to the final species identification (Supplemental Table S1 and Table 1).

Table 1. Criteria to assign confidence to species identification based on DNA sequence quality, percent match with sequence to databanks, and quality of databank references: these criteria were evaluated, and sequences were given a final confidence score (high, medium, and low).

\begin{tabular}{|c|c|c|c|}
\hline & High & Med & Low \\
\hline \multicolumn{4}{|l|}{ DNA Sequence Quality } \\
\hline High Quality Bases & $>95 \%$ & $80-95 \%$ & $<80 \%$ \\
\hline Alignment & $>90 \%$ & $50-90 \%$ & $<50 \%$ \\
\hline Ambiguities & $<5$ & $5-15$ & $>15$ \\
\hline \multicolumn{4}{|l|}{ Sequence Match on Databank } \\
\hline$\%$ Similarity & $>98 \%$ & $90-98 \%$ & $<90 \%$ \\
\hline \multicolumn{4}{|l|}{ Databank References } \\
\hline Peer review and accessibility & $\begin{array}{l}\text { Published, } \\
\text { accessible }\end{array}$ & $\begin{array}{l}\text { Published, not } \\
\text { accessible }\end{array}$ & $\begin{array}{l}\text { Not published, not } \\
\text { accessible }\end{array}$ \\
\hline Photo & Yes & No & Wrong photo \\
\hline $\begin{array}{l}\text { Collection Details } \\
\text { (e.g., lat/long, collector, and identifier) }\end{array}$ & Full details & Minimal details & No details \\
\hline Consistency of top hits & $\begin{array}{l}\text { Top } 10 \text { all same } \\
\text { species }\end{array}$ & $\begin{array}{l}5 \text { of } 10 \text { top hits } \\
\text { same species }\end{array}$ & $\begin{array}{l}\text { Mix of species for } \\
\text { top } 10 \text { hits }\end{array}$ \\
\hline
\end{tabular}

\section{Results}

A total of 1724 parrotfish individuals from 19 species were recorded (Table 2) during UVCs in coral reef, macroalgal bed, seagrass, and lagoon habitats. No parrotfishes were observed in the mangrove habitat, and thus, the mangrove habitat was excluded from analysis. We are confident that we have captured a large proportion of parrotfish species richness in our surveyed area and that these results compare with others from the region [50-52] (Supplemental Table S1). 
Table 2. Parrotfish (family: Labridae, subfamily: Scarinae) species identified by DNA analysis of juveniles collected in non-reef habitats and species observed as adults on underwater visual census surveys across multiple habitats: $1=$ present in surveys or collections, $0=$ not observed or identified. Data is separated by juveniles and adults and then also recorded by habitat type. Total count is the total number of each species collected as juveniles in non-reef habitats. All = observed in any habitat on visual surveys, $\mathrm{CR}=$ Coral Reef, $\mathrm{MA}=$ Macroalgal bed, $\mathrm{SG}=$ Seagrass, and LAG = Lagoon .

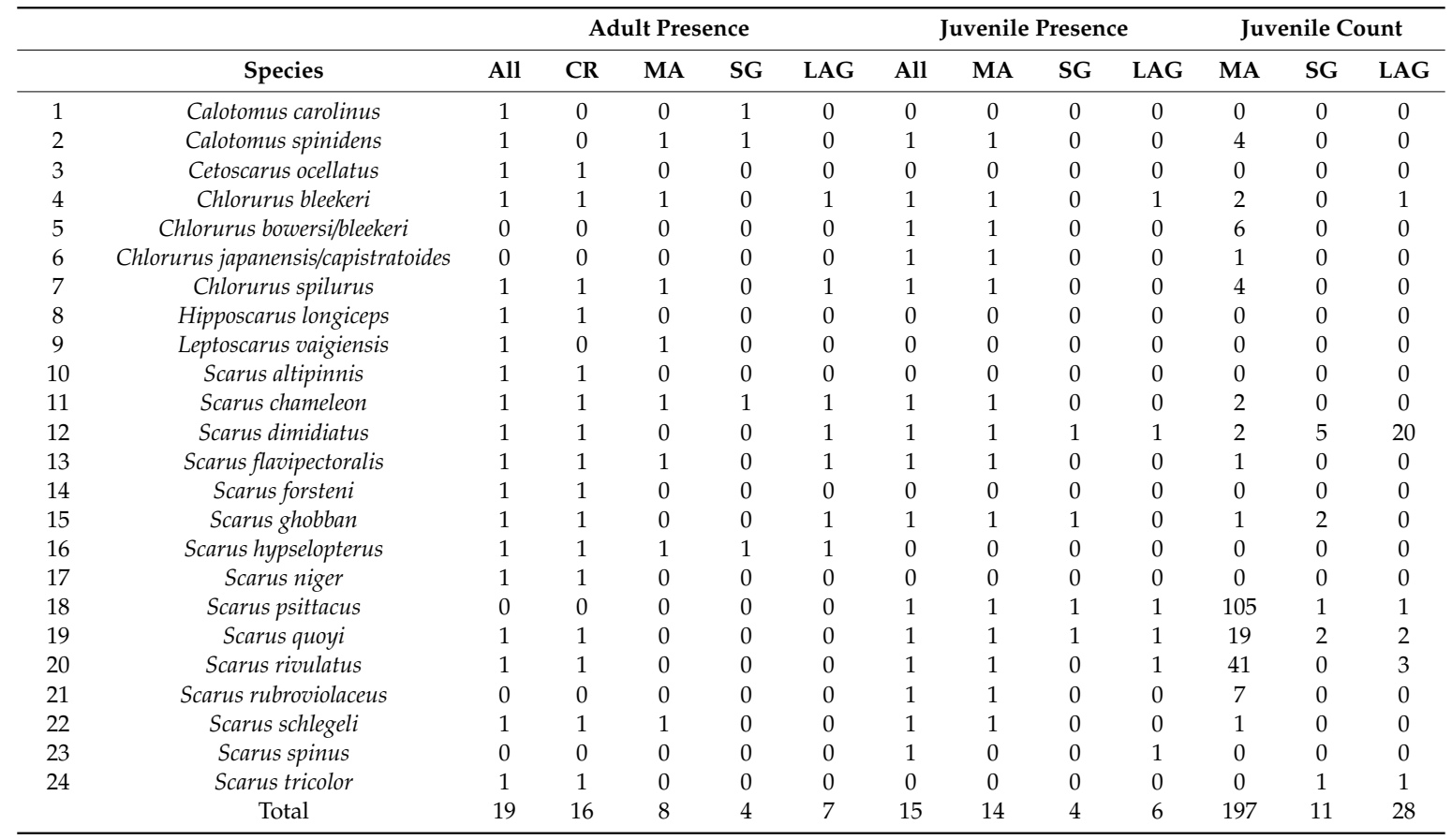

A total of 241 juvenile individuals were collected from non-reef habitats spanning the length of southwestern Siquijor (Figure 1). Of these juveniles collected, 27 were easily identified as Scarus dimidiatus, as they were slightly larger individuals, and were differentiated from other species by their characteristic yellow body and vertical black bars on the dorsal side [40]. These S. dimidiatus samples were therefore not included in DNA analysis. Fin clips of the remaining individuals $(n=214)$ were sent for sequencing, and 209 of those sequences were of good enough quality to BLAST for species identification (Supplemental Table S2). Most BLASTS were run with consensus alignments, but 34 alignments were of low quality. Thus, the higher quality forward or reverse sequences were used instead (Table S2). From the 209 samples used for species identification, 112 (52\%) were graded as high-confidence identifications, 82 (38\%) were graded as medium confidence, and $15(7 \%)$ samples were graded with low confidence (Table 3). Phylogenetic agreement of species further confirmed species identifications (Supplemental Figure S1). Most juveniles were collected from macroalgal habitat $(n=197)$, with much fewer collected from seagrass $(n=11)$ or lagoon $(n=28)$ habitats (Table 2).

We identified 15 parrotfish species (subfamily: Scarinae) or species sets based on collection of juveniles (Table 3), 14 by DNA results and one by observation (S. dimidiatus). The two species sets were Chlorurus japanesnsis/capistratoides $(\mathrm{n}=1)$, and Chlorurus bleekeri/bowersi $(\mathrm{n}=6)$. We retained these identifications as a potential of two species because top hits from GenBank and BOLD were a mix of the two species. We felt that they were appropriate to present as such, as the two species in each set were highly phylogenetically related [53]. For the remaining results and discussion, C. bleekeri/bowersi, and $C$. japanensis/capistratoides will each represent one "species" in the following results.

Of the 15 juvenile parrotfish species identified, 10 were also observed on UVC circular plots as adults and five juvenile species were not observed as adults on any circular plot in any habitat. In total, UVC surveys of adult parrotfish recorded 19 species across seagrass, macroalgae, lagoon, and coral reef habitats (Table 2). Of the 19 adult parrotfishes observed on surveys, eight (42\%) were coral reef 
exclusive habitat users, eight (42\%) were multi-habitat users, and three $(16 \%)$ were non-reef habitat users (Figure 2). Categorizing the 15 juvenile species by their adult habitat use patterns (based on surveys of adults) indicated that two (13\%) species of juveniles collected in non-reef habitats were coral reef exclusive habitat users, one $(7 \%)$ species was a non-reef exclusive habitat user, seven $(47 \%)$ were multi-habitat users, and five (33\%) species were not observed on any visual census observations in any habitats (Figure 2). However, if we reconsider our classification, species originally classified as coral reef exclusive species but observed in non-reef habitats as juveniles would hence be multi-habitat users. Additionally, juveniles collected in non-reef habitat but not observed as adults in any habitat likely occupy another habitat not surveyed, and this could also be classed as a multi-habitat user. With this reclassification, $93 \%$ of species collected as juveniles could then be considered multi-habitat users. This contrasts adult surveys, where only $42 \%$ of species were classified as multi-habitat users.

Table 3. Juvenile parrotfish collections and confidence associated with species identification accuracy: Total length (TL) range is the minimum and maximum TLs for each species.

\begin{tabular}{|c|c|c|c|c|c|c|}
\hline Count & Species & High & Med & Low & Total & TL Range (mm) \\
\hline 1 & Scarus psittacus & 80 & 24 & 3 & 107 & $18-51$ \\
\hline 2 & Scarus rivulatus & 1 & 35 & 8 & 44 & $13-57$ \\
\hline 3 & Scarus dimidiatus & 27 & & & 27 & $32-98$ \\
\hline 4 & Scarus quoyi & 15 & 6 & 2 & 23 & $17-87$ \\
\hline 5 & Scarus rubroviolaceus & & 7 & & 7 & $24-75$ \\
\hline 6 & Chlorurus bowersi/bleekeri & & 4 & 2 & 6 & $21-39$ \\
\hline 7 & Calotomus spinidens & 4 & & & 4 & $36-42$ \\
\hline 8 & Chlorurus spilurus & 4 & & & 4 & $22-67$ \\
\hline 9 & Chlorurus bleekeri & 1 & 2 & & 3 & $29-38$ \\
\hline 10 & Scarus ghobban & 2 & 1 & & 3 & $46-118$ \\
\hline 11 & Scarus chameleon & & 2 & & 2 & $29-38$ \\
\hline 12 & Scarus flavipectoralis & 2 & & & 2 & 31 \\
\hline 13 & Chlorurus japanensis/capistratoides & & 1 & & 1 & 29 \\
\hline 14 & Scarus schlegeli & 1 & & & 1 & 39 \\
\hline \multirow[t]{2}{*}{15} & Scarus spinus & 1 & & & 1 & 21 \\
\hline & Grand Total & 112 & 82 & 15 & 209 & \\
\hline
\end{tabular}

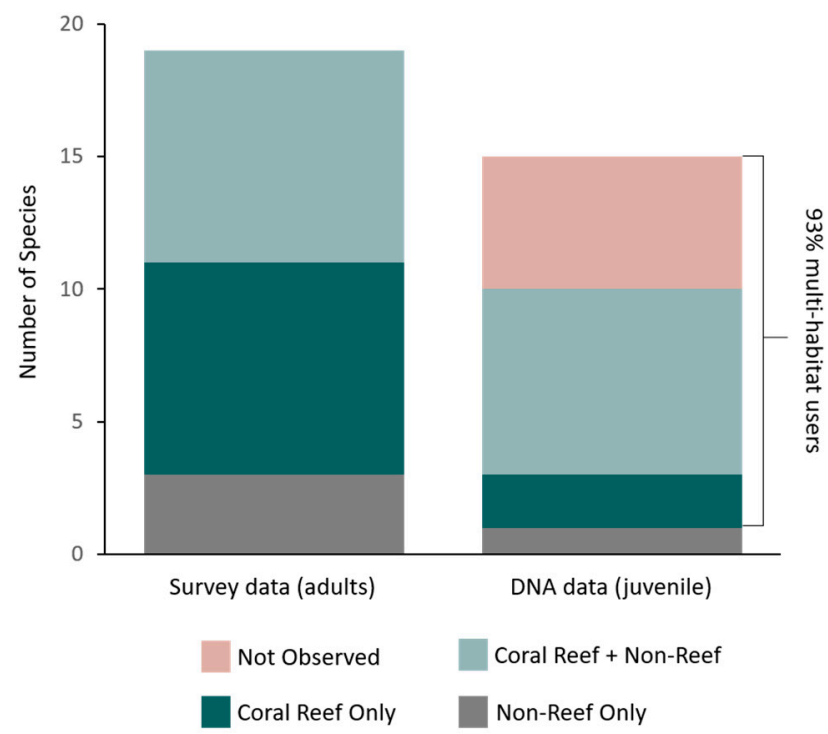

Figure 2. Habitat use classification for parrotfish species: classification colours are based on observations from adult parrotfish surveys across all habitat types. Classification of adults observed on surveys (left) and juveniles collected in non-reef habitats (right): Coral Reef only (dark green) are species only observed as adults on coral reef habitat, Coral Reef + Non-Reef (light green) are species observed as adults on both coral reef and any non-reef habitat, Non-Reef only (grey) are adults observed only in non-reef habitats, and Not Observed (beige) are species identified with DNA analysis from juvenile collections in non-reef habitats but not seen as adults on visual surveys in any habitat. 
On coral reefs, 16 parrotfish species were observed as adults and nine (56\%) of those species were collected as juveniles in non-reef habitats (Figure 3, Table 2). Those nine species make up $50 \%$ of the total average density of parrotfishes on coral reefs. For macroalgal beds, eight species were observed as adults on surveys and six (75\%) were collected as juveniles (Figure 3). Those six species make up 58\% of the total average density of parrotfish adults in macroalgal habitat. For lagoons, juveniles collected represented six (85\%) of the seven adult parrotfish species observed. Those six species make up $91 \%$ of the total average density of adult parrotfishes seen in a lagoon habitat (Figure 3). Finally, for adults observed in a seagrass habitat, only four parrotfish species were observed as adults, and we captured two $(50 \%)$ of those species in our juvenile collections. Those two species represented $94 \%$ of the total average density of adults in seagrass beds (Figure 3).

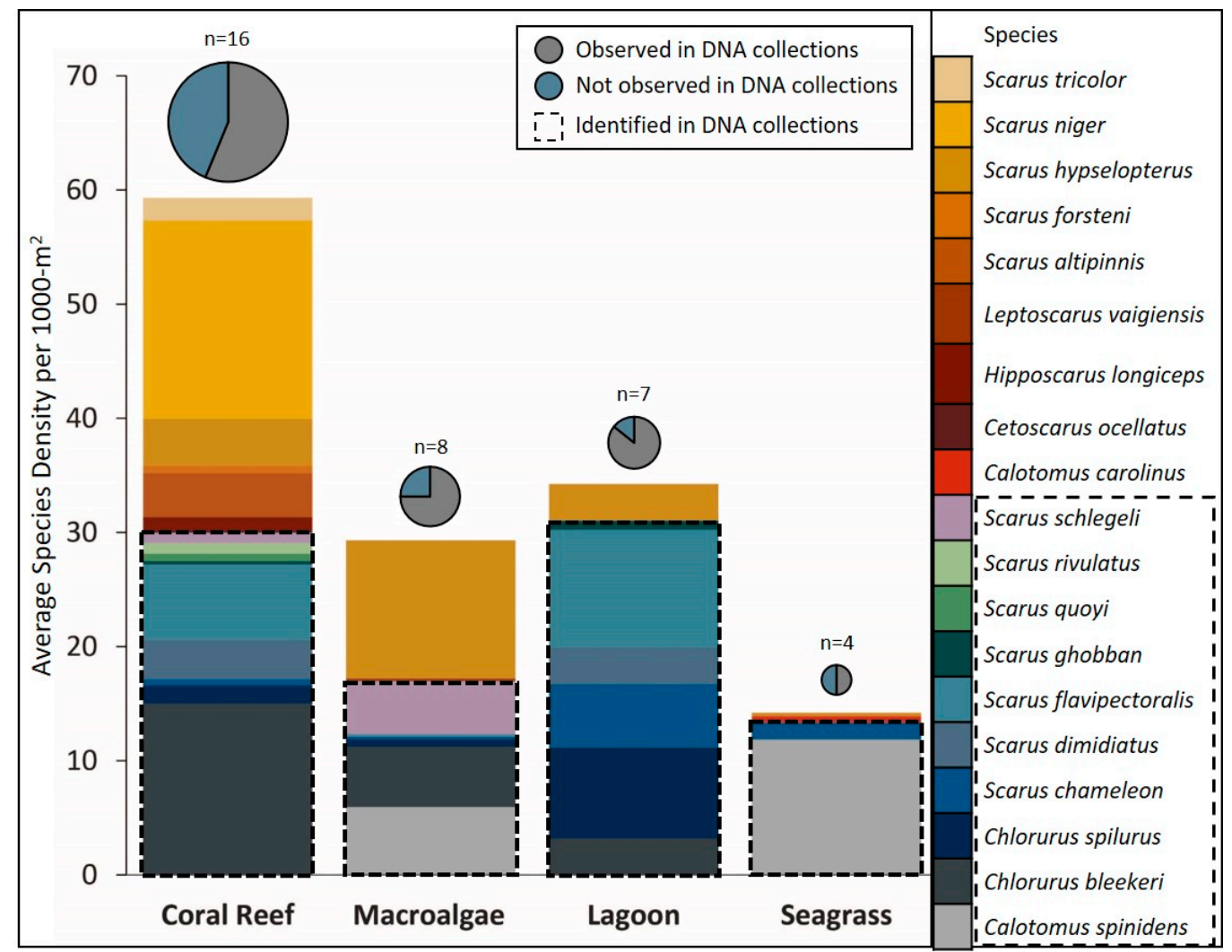

Figure 3. Average density of adult parrotfish species observed in visual census surveys within each habitat type: the colours represent different species. Dashed boxes on each bar outline the species identified in DNA analysis from juvenile collections in non-reef habitats. Pie graphs represent the total number of species observed in each habitat type, separated by whether the species were observed in DNA collections of juveniles in non-reef habitats (grey) or not observed in collections (blue). Size of the pie graph portrays total number (n) of species observed as adults within each habitat type.

The species composition and richness of juveniles collected in seagrass, macroalgae, and lagoon habitats were different from those for adults observed in UVC surveys of these habitats (Figure 4). Overall, juvenile identifications were dominated by Scarus psittacus (45.3\%), Scarus rivulatus (18.6\%), and Scarus dimidiatus (11.4\%) (Table 2). In comparison with adult survey data, S. rivulatus was identified in coral reef habitat only, S. dimidiatus was observed in coral reef and lagoon habitats, and S. psittacus was not observed on any habitat as an adult. In seagrass habitat, we identified four species as juveniles and observed four species as adults (Figure 4). In macroalgal habitat, 14 species were identified as juveniles and eight were recorded as adults. In lagoon habitat, six species were identified as juveniles compared to seven species as adults. Furthermore, the species composition looks vastly different between adult and juveniles in the same habitats (Figure 4). For macroalgal habitats, adults were 
dominated by Scarus hypselopterus and juveniles in macroalgae were dominated by Scarus psittacus. In lagoon habitats, adults were dominated by Scarus flavipectoralis and Chlorurus spilurus whereas juveniles were dominated by Scarus dimidiatus. In seagrass habitat, adult parrotfishes were dominated by Calotomus spinidens (Table S2), compared with Scarus dimidiatus for the juveniles (Figure 4). Interestingly, for all non-reef habitats, the most common adult observed on surveys was not collected as juveniles in their respective habitats.

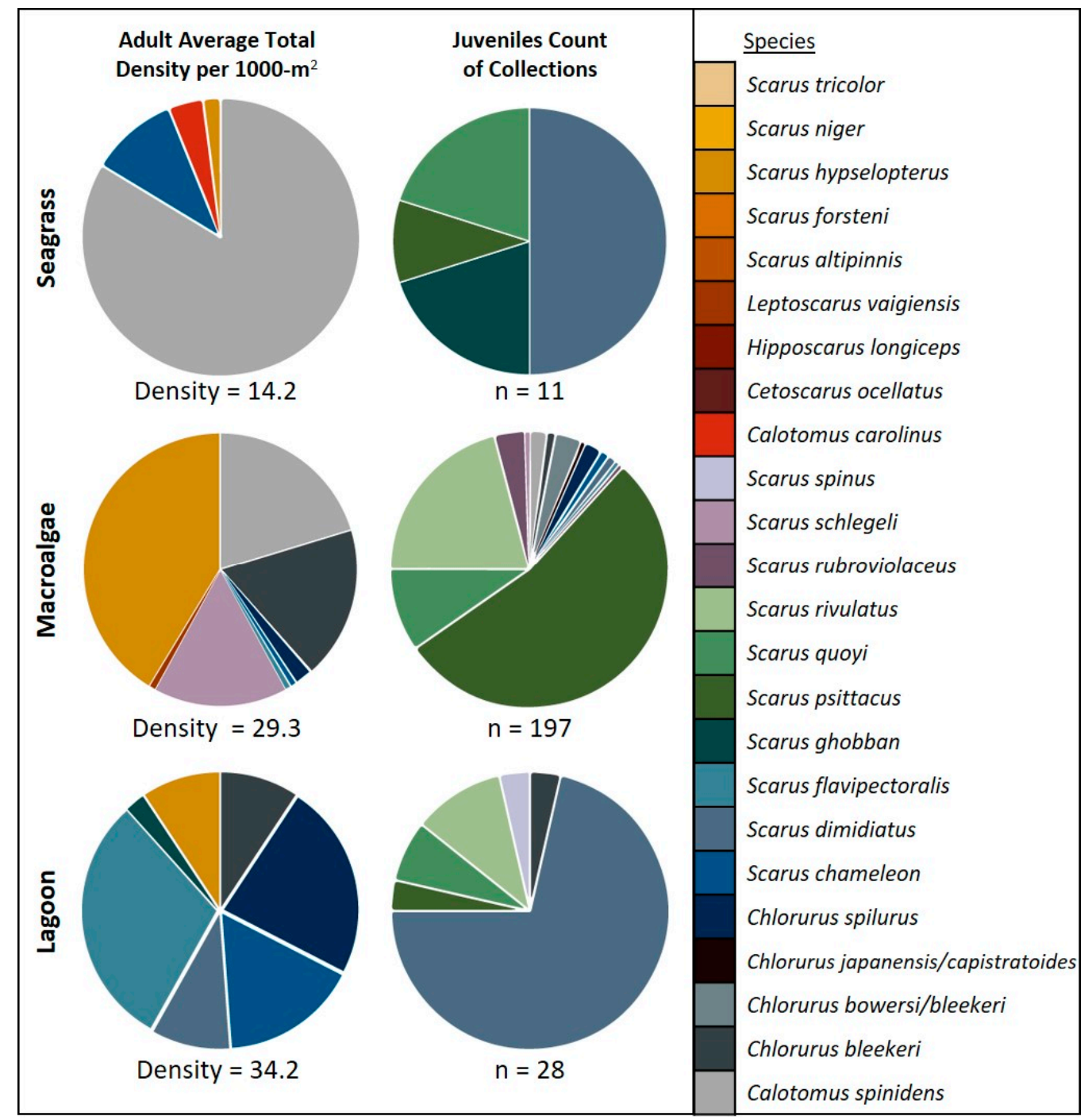

Figure 4. Comparing parrotfish species composition between seagrass habitat (top), macroalgal bed habitat (middle), and lagoon habitat (bottom) for adults identified on surveys (left) and juveniles identified through DNA analysis (right): adults are represented as the average total density per $1000-\mathrm{m}^{2}$. Juveniles are reported as the total number of individuals collected in each habitat, reported as $n$.

There were nine parrotfish species that were observed as adults and not captured as juveniles in non-reef habitats with the collections (Table 2). These were Calotomus carolinus, Cetoscarus ocellatus, Hipposcarus longiceps, Leptoscarus vaigiensis, Scarus altipinnis, Scarus forsteni, Scarus hypselopterus, Scarus niger, and Scarus tricolor. Six of those nine species are coral reef exclusive habitat users based on UVC.

For parrotfish species that are distinct and visually identifiable as juveniles (Cetoscarus ocellatus, Chlorurus microrhinos, Scarus niger, and Scarus dimidiatus), visual surveys revealed subtle patterns (Table 4). Cetoscarus ocellatus and Chlorurus microrhinos were observed only on coral reefs, with only one observation each as juveniles. Scarus dimidiatus was observed as juveniles on coral reefs and lagoon 
habitats, which is consistent with the adult surveys and juvenile collections. Scarus niger was the most abundant species as adults on coral reefs (Supplemental Table S3 and Figure 4) and was observed as a juvenile mostly on coral reefs, but two observations were recorded for Scarus niger in the lagoon habitat.

Table 4. Presence (1) from visual census in different habitats for parrotfish species with unique coloration patterns that enable confident identifications at the juvenile stage: outlined cells represent juveniles which were also identified from DNA analysis during collections in non-reef habitats. CR = Coral Reef, $\mathrm{MA}=$ macroalgal bed, $\mathrm{LAG}=$ lagoon, and $\mathrm{SG}=$ seagrass .

\begin{tabular}{|c|c|c|c|c|c|c|c|c|}
\hline \multirow[b]{2}{*}{ Species } & \multicolumn{4}{|c|}{ Juvenile } & \multicolumn{4}{|c|}{ Adult } \\
\hline & CR & MA & LAG & SG & CR & MA & LAG & SG \\
\hline Cetoscarus ocellatus & 1 & & & & 1 & & & \\
\hline Chlorurus microrhinos & 1 & & & & & & & \\
\hline Scarus dimidiatus & 1 & & 1 & & 1 & & 1 & \\
\hline Scarus niger & 1 & & 1 & & 1 & & & \\
\hline
\end{tabular}

UVC surveys showed that parrotfish less than 10-cm TL were 34 times more abundant in non-reef habitats compared to coral reefs and that non-reef habitats had $97 \%$ of all parrotfish individuals less than 10-cm TL (Figure 5). Lagoon was the primary habitat for small parrotfish individuals, followed by macroalgal beds. It is important to note that the variability of observations in lagoons was very high (Supplemental Table S4). As fish get bigger, the proportion of fish observed in non-reef habitats decreases, and larger parrotfishes $(>15-\mathrm{cm}$ TL) were almost exclusively present in the coral reef habitat.

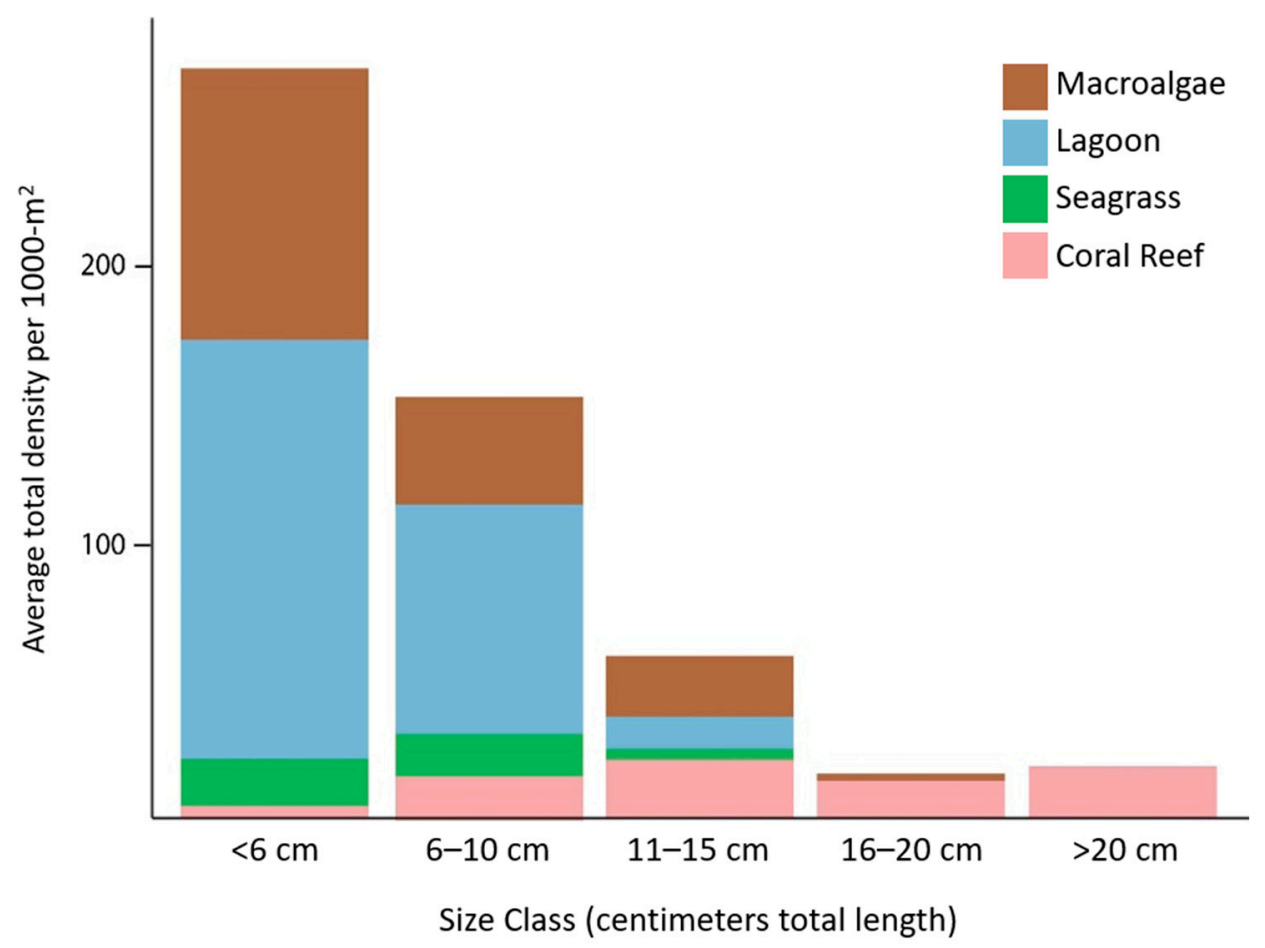

Figure 5. Average parrotfish density of all individuals observed on visual census surveys within each habitat type.

\section{Discussion}

This study demonstrated considerable use of non-reef habitats by juvenile parrotfishes, with ontogenetic shifts representing prevalent and important life-history transitions for many species. Moreover, for some of these species collected as juveniles, adults were observed only on the reef, suggesting that ontogenetic habitat shifts occur. From visual surveys, we observed substantially 
more small parrotfishes in non-reef habitats compared to coral reefs, further providing evidence that macroalgal, lagoon, and seagrass habitats on Siquijor potentially act as nursery habitats for some parrotfish species. To our knowledge, this is one of the few studies that used DNA analysis to verify species identifications of juvenile parrotfish to explore habitat use patterns across a diverse seascape [46].

Parrotfishes across all life stages, particularly juveniles, can be extremely difficult to identify correctly to the species level. Although time consuming and expensive compared to visual surveys, DNA results can allow for direct links to be made between juvenile and adult stages and can even reveal the presence of species that may not be observed in visual surveys. For example, Scarus psittacus was the most abundant species $(n=107,46 \%)$ from juvenile collections in non-reef habitats but was not observed on surveys in any habitat. S. psittacus has previously been observed in the Philippines on coral reefs [51,52] and on coral reefs in the same area as these surveys [50]. Furthermore, S. psittacus is a species frequently observed in fish markets in the local area (personal observations). The ecology of S. psittacus can explain the lack of observations on surveys, as they mainly occupy areas of the reef with larger sand patches (G.R.R. personal observation), often within a back reef system characterized by sand and rubble, or lagoon areas of the middle and outer coral shelves of the Great Barrier Reef (GBR) $[51,54,55]$. These back-reef areas were not targeted in UVC for this study. The reef flat and back-reef areas are important habitats in tropical seascapes [56], and we may be missing key features of fish communities by not including them in surveys. These results highlight the need to expand surveys to areas surrounding coral reefs (e.g., sandy habitat adjacent to coral reefs and immediate back-reef habitats). S. psittacus are also known to school, and perhaps this attribute skewed the results of the juvenile collections by collecting entire schooling groups. The other species not identified in adult surveys but collected as juveniles in non-reef habitat were Chlorurus japanensis/capistratoides, Scarus rubroviolaceus, and Scarus spinus. These species are relatively rare on Philippine coral reefs in this region [51] and thus are unlikely to be observed with any regularity. Capturing rare species in an ecosystem can be critical, as they can often be the most vulnerable to disturbance and exploitation impacts $[57,58]$.

It is important to acknowledge that collections of juvenile parrotfishes did not capture all species observed on visual surveys. For example, the most abundant adult parrotfish on coral reefs (Scarus niger) was not found in the juvenile non-reef collections. S. niger is one the few species that can be confidently identified as a juvenile, and while most $S$. niger juveniles were observed in UVC plot surveys on coral reefs, two observations were made in lagoon habitat (Table 4). Six of the nine species observed as adults but not as juveniles were classified as exclusive users of coral reefs. Perhaps, these juveniles recruit directly to coral reefs, and as our collections were focused on non-reef habitats, species that settle directly on reefs would have been missed during our juvenile collections. To advance our knowledge, further research should collect parrotfish juveniles from coral reef habitats as well as non-reef habitats.

We also acknowledge that we cannot provide $100 \%$ certainty for all the species identifications derived from DNA analysis. Some hits on GenBank and/or BOLD selected other species not listed here; however, these hits were unreliable, were of poor quality, were incorrect, and/or were unverifiable, and thus were removed from consideration. This highlights the importance of improved vetting of GenBank additions and of providing supplemental information when uploading sequences, particularly for species groups that are difficult to identify such as parrotfishes. We suggest that DNA sequences should be calibrated to a sequence for which the species identification has been verified. We endeavoured to scrupulously check all species hits but acknowledge that DNA analysis brings its own caveats. Furthermore, using only one gene fragment (COI) rather than a multilocus approach limits our ability to identify samples to the species level. However, the COI gene has been used widely $[46,59]$ and is an appropriate method for identifying species [60].

In Siquijor, lagoon and macroalgal habitats had the greatest number of parrotfish juveniles. In contrast with other studies, there were zero visual observations of parrotfishes in mangrove 
habitats. Strong relationships between parrotfishes and mangrove habitats have been shown in the Caribbean [7,61,62], Australia [63-66], and the Indian Ocean [29,39]. The use of mangroves by fish is likely tidally influenced, such that areas with high tidal flux have reduced reliance of fish on mangrove habitat $[38,67]$. In Siquijor, mangroves are mostly only accessible to fish at high tides and are also quite muddy and silty due to the planting of Rhizophora stands. Seagrass beds are also often exposed at low tide, which may further support our evidence that seagrass beds were not as important as a nursery area for juvenile parrotfishes. The lagoon habitat is well recorded as a juvenile nursery habitat for fish across a wide range of locations [68-71]. Care should be taken with the results here, as the variability in juvenile parrotfish observations in lagoons was extremely high on Siquijor. This variability is likely due to the tendency for small juveniles of parrotfish to school, combined with the patchiness of structured habitat in the lagoon, which consists predominately of sand scattered with seagrass and isolated coral patches. Therefore, we suspect that observations of large schools of juvenile parrotfishes were possibly chance encounters. Recently, macroalgal habitat has become a major focus of research in tropical systems, and research has shown that macroalgal beds can be more important than seagrass beds as a nursery area for juvenile fishes $[8,37,42]$. Macroalgal beds have high levels of epiphytes and invertebrate epifauna [42,72], which are often the target prey for juvenile parrotfishes $[15,17,45]$. Considering the potential importance of macroalgal beds for coral reef fishes, there has been relatively little research conducted in these habitats under the framework of understanding how macroalgal beds may contribute to abundance patterns of coral reef fishes $[8,30,37]$. We conclude that macroalgal beds are the dominant nursery habitat for juvenile parrotfish in Siquijor.

Parrotfishes have long been documented as multi-habitat users [30,37-39,44,71]. Of the species collected in non-reef habitats as juveniles, $93 \%$ of those could be classified as multi-habitat users. This starkly contrasts the results from the adult survey data, where only $42 \%$ of species would be classified as multi-habitat users. This discrepancy between the two data sets implies that visual surveys alone may not be capturing the full extent to which parrotfish species use a seascape and that we may be underestimating the degree to which fishes utilize multiple habitats. While we acknowledge that the majority of parrotfish individuals are on coral reefs, their presence in non-reef habitats implies connections between different habitats in a seascape. Two of the three most abundant species collected as juveniles and observed as adults on UVC were classified as coral reef exclusive habitat users (Scarus rivulatus and Scarus quoyi). Relatively little is known about the habitat use patterns or life stages of S. quoyi. However, S. rivulatus has been well studied but mainly focused on coral reefs. On the GBR, S. rivulatus is a species characteristic of mid-shelf reefs, often being present in lagoons and back reef habitats [54,55,73], and has been shown to have limited home range movements as adults [74].

Non-reef habitat use as juveniles might be contingent on whether these habitats are near coral reefs, as we see here in Siquijor, Philippines. The seminal work on juvenile parrotfishes by Bellwood and Choat [40] shows distinct differentiation in habitat use across coral reefs. This study was focused on the reef slope, reef flat, and back reef on the GBR. Many of the species identified in the present study in non-reef habitats were also recorded by Bellwood and Choat [40] across multiple coral reef locations. We argue that occurrences are possible both in reef and non-reef habitats and that these species are opportunistically using non-reef habitats such as macroalgal beds when they are available and in close spatial proximity to their adult habitat. The links between non-reef habitats and coral reefs are therefore likely a function of habitat availability and the spatial connectivity of a seascape. Moreover, it is necessary to recognize that, if juveniles are present in non-reef habitats, they are likely settling there as recruits. Recruitment and settlement dynamics are complex, but individuals do have the ability to settle to specific microhabitats [75-77]. Habitat availability, food availability, density dependence, and predation are all pressures driving settlement and post-settlement survival. Most certainly, these are all influencing the presence and abundance of juvenile fishes we explored here. Furthermore, island-scale variability in available habitat can be the main driver of parrotfish diversity, as shown in Micronesia [78]. It is not unreasonable to hypothesize that nursery habitat is acting as a recruitment bottleneck for adult parrotfish diversity here in Siquijor, especially considering the relatively high 
larval connectivity in this region [79]. However, nursery habitat bottlenecks will not be relevant to all species (e.g., species recruiting directly to coral reefs) and will be more important for species that lack the flexibility to recruit to multiple habitats. Importantly, Siquijor was specifically selected because of its diverse seascape, with high spatial proximity of multiple habitats to coral reefs. The conclusions we draw here must be considered through the lens of a highly connected seascape and may not be applicable to another coral reef system where habitats are much more spatially segregated (e.g., the GBR). Further research should incorporate the spatial dynamics of the seascape when exploring fish-habitat patterns and critically evaluate whether flexibility in habitat use is driven by the spatial availability and connectivity of habitats.

The underlying assumption behind ontogenetic habitat shifts is that the benefit of using an alternative habitat must outweigh the risk [9-11]. Here, following the nursery trade-off hypothesis, the presumed benefit for parrotfishes to use non-reef habitats as juveniles would be reduced predation with the trade-off of reduced growth rates. Although research on parrotfish growth demonstrates that the earlier life phases have the fastest growth, the lower size limit for species evaluated is usually $10-\mathrm{cm}$ TL [80]. One of the few papers that explores growth rates of small juvenile parrotfish does demonstrate slower growth when individuals are under 10-cm TL (for S. rivulatus and S. schlegeli) [81], which would confirm the nursery trade-off hypothesis of slow growth for small juveniles. Furthermore, at very early life stages, parrotfishes have been shown to be herbivorous [45] or carnivorous [15,17], before switching to a protein-rich diet of autotrophic cyanobacteria present in sand, in the epilithic algal matrix (EAM), and/or imbedded in calcareous reef substrate $[16,82]$. This dietary switch, which has been observed at around 10-cm TL [45], would further support the change in diet that mirrors the growth relationships observed in Lou [81], where the fastest growth would occur once individuals switch to a cyanobacteria diet. Furthermore, juvenile parrotfishes have the jaw morphology to accommodate herbivory and carnivory before development of the beak-like fused teeth which characterize this group as scrapers and excavators in their adult stages [17]. Although Bonaldo and Bellwood [83] showed that S. rivulatus targeted EAM regardless of size class, they performed feeding observations of $S$. rivulatus on coral reef habitat only. Potentially, these species may exhibit greater flexibility in diet in their juvenile stage when non-reef habitats are available and used, emphasizing that non-reef habitat use may be opportunistic rather than obligatory. To fully understand ontogenetic dietary changes, feeding observations, gut content analysis, and biomarkers of targeted nutrients should be studied. Furthermore, such research should be conducted across multiple habitats and life stages to explore how ontogenetic shifts may be mediated by the spatial characteristics of the seascape.

Dietary changes may also coincide with increased movement [19,44], leading to ontogenetic migrations to coral reefs to acquire their target food source as adults. Bradley et al. [44] observed early juvenile parrotfishes in two habitat types (vegetated habitat and coral reef), but late juvenile phase parrotfishes occupied three habitats (vegetated habitats, rocky reefs, and coral reefs). Streit and Bellwood [18] also correlated parrotfish size with willingness to return to their home reef when experimentally moved, where larger fishes moved greater distances. Welsh et al. [19] identified the greatest change in relative home range size of parrotfishes occurring when species were less than 10-cm TL. Plasticity in movement based on available habitat has been evaluated for some parrotfish species, where variation in movement differed substantially based on resource availability [19] and spatiotemporal scale [84], but such evaluations have focused on adults on coral reefs. The potential for ontogenetic shifts to coincide with habitat migrations are clearly present, yet these movements are mediated by habitat availability, spatial connectivity, and resource availability and should be explored further.

On a diverse seascape in the Philippines, we found that lagoon, macroalgal beds, and seagrass beds are habitats for juvenile parrotfishes. Of the juveniles collected in non-reef habitats, $93 \%$ of those species should be classified as multi-habitat users. Furthermore, the species composition of adults and juveniles was quite distinct in the same habitats, indicating potential ontogenetic habitat shifts. Considering the ecological and economic importance of parrotfishes, there exists a significant 
knowledge gap about their habitat use patterns as juveniles, especially when framed in the context of potential ontogenetic habitat shifts across a seascape. Our research provides yet more evidence of the connectivity between different benthic habitats of a seascape. The strength of the link between nursery habitat and coral reefs can have strong consequences on adult populations [85] and can lead to synergistic effects of effective protection with marine reserves [66]. This is particularly relevant for locations like the Philippines, where reserves rarely include these habitats. Incorporating knowledge of ontogenetic movement into marine reserve design and population dynamics can provide better estimations of reserve impact on populations [1,86-88]. To appropriately protect species, we must first understand how species use the wider seascape and identify what habitats might be important for populations.

Supplementary Materials: The following are available online at http:/www.mdpi.com/1424-2818/12/10/376/s1, Table S1: Parrotfish species richness data from publications in the Negros Oriental region with a comparison to this publication (Sievers et al.); Table S2: Results from sequence cleaning and blast data: F HQ and R HQ are the percentages of high-q $\neg$ uality base pairs for the forward (F) and reverse (R) sequences. \%GC is the percent of base pairs C and G. Alignment score is percent alignment between forward and reverse sequences. Ambiguities are for the consensus sequence. BLAST confidence was assigned based on criteria detailed in the main text. Accession numbers are for GenBank; Table S3: Average density per 1000- $\mathrm{m}^{2}$ of adult parrotfish species observed on visual transects, separated by habitat type; Table S4: Mean and standard deviation (in parenthesis) of parrotfish density (individuals per 1000- $\mathrm{m}^{2}$ ) across habitat types, grouped by size (centimetres) bins of total length estimates (TL) from visual surveys; Figure S1: Phylogenetic tree generated in Geneious software for DNA sequences: The Geneious tree building method used neighbour joining tree and the Tamura-Nei genetic distance model, and no outgroup with $65 \%$ similarity.

Author Contributions: Conceptualization, K.T.S. and R.A.A.; methodology, K.T.S. and R.A.A.; formal analysis, K.T.S.; resources, K.T.S., R.A.A., and G.R.R.; data curation, K.T.S., R.A.A., and A.A.B.; writing-original draft preparation, K.T.S.; writing-review and editing, K.T.S., R.A.A., A.A.B., and G.R.R.; supervision, R.A.A. and G.R.R.; project administration, K.T.S., R.A.A., and A.A.B.; funding acquisition, K.T.S. and G.R.R. All authors have read and agreed to the published version of the manuscript.

Funding: This research was funded by the ARC Centre of Excellence for Coral Reef Studies, the PADI Foundation grant number 32841, Department of Science and Technology-National Academy of Science and Technology, and a James Cook University Postgraduate Research Scholarship.

Acknowledgments: J.H. Choat provided crucial knowledge and guidance to this work. Angel Alcala and Emily Layos provided essential logistical support in the Philippines. Manuel and Noe Bucol were instrumental in field collections. Carolyn Smith-Keune, Nikolaos Andreakis, Maddie Cooper, and Grace Cole, from the MEEL laboratory at James Cook University, dedicated their guidance and expertise for DNA analysis. Mia Comeros-Raynal and Katie Sambrook provided guidance and encouraging conversations over the course of this work. Finally, thanks to Eva McClure for personal and scientific support.

Conflicts of Interest: The authors declare no conflict of interest. The funders had no role in the design of the study; in the collection, analyses, or interpretation of data; in the writing of the manuscript; or in the decision to publish the results.

\section{References}

1. Nagelkerken, I.; Sheaves, M.; Baker, R.; Connolly, R.M. The seascape nursery: A novel spatial approach to identify and manage nurseries for coastal marine fauna. Fish Fish. 2015, 16, 362-371. [CrossRef]

2. Beck, M.W.; HECK, K.L.; ABLE, K.W.; Childers, D.L.; Eggleston, D.B.; Gillanders, B.M.; Halpern, B.; Hays, C.G.; HOSHINO, K.; Minello, T.J.; et al. The Identification, Conservation, and Management of Estuarine and Marine Nurseries for Fish and Invertebrates. Bioscience 2001, 51, 633-641. [CrossRef]

3. Lefcheck, J.S.; Hughes, B.B.; Johnson, A.J.; Pfirrman, B.W.; Rasher, D.B.; Smyth, A.R.; Williams, B.L.; Beck, M.W.; Orth, R.J. Are coastal habitats important nurseries? A meta-analysis. Conserv. Lett. 2019, e12645. [CrossRef]

4. Sheaves, M.; Baker, R.; Nagelkerken, I.; Connolly, R.M. True value of estuarine and coastal nurseries for fish: Incorporating complexity and dynamics. Estuaries Coasts 2015, 38, 401-414. [CrossRef]

5. Adams, A.J.; Dahlgren, C.P.; Kellison, G.T.; Kendall, M.S.; Layman, C.A.; Ley, J.A.; Nagelkerken, I.; Serafy, J.E. Nursery function of tropical back-reef systems. Mar. Ecol. Prog. Ser. 2006, 318, 287-301. [CrossRef] 
6. Dahlgren, C.P.; Kellison, T.G.; Adams, A.J.; Gillanders, B.M.; Kendall, M.S.; Layman, C.A.; Ley, J.A.; Nagelkerken, I.; Serafy, J.E. Marine nurseries and effective juvenile habitats: Concepts and applications. Mar. Ecol. Prog. Ser. 2006, 312, 291-295. [CrossRef]

7. Nagelkerken, I.; van der Velde, G.; Gorissen, M.W.; Meijer, G.J.; van't Hof, T.; den Hartog, C. Importance of mangroves, seagrass beds and the shallow coral reef as a nursery for important coral reef fishes, using a visual census technique. Estuar. Coast. Shelf Sci. 2000, 51, 31-44. [CrossRef]

8. Fulton, C.J.; Berkström, C.; Wilson, S.K.; Abesamis, R.A.; Bradley, M.; Åkerlund, C.; Barrett, L.T.; Bucol, A.A.; Chacin, D.H.; Chong-seng, K.M.; et al. Macroalgal meadow habitats support fish and fisheries in diverse tropical seascapes. Fish Fish. 2020, 21, 1-18. [CrossRef]

9. Dorenbosch, M.; Grol, M.G.G.; de Groene, A.; van Der Velde, G.; Nagelkerken, I. Piscivore assemblages and predation pressure affect relative safety of some back-reef habitats for juvenile fish in a Caribbean bay. Mar. Ecol. Prog. Ser. 2009, 379, 181-196. [CrossRef]

10. Grol, M.G.G.; Nagelkerken, I.; Rypel, A.L.; Layman, C.A. Simple ecological trade-offs give rise to emergent cross-ecosystem distributions of a coral reef fish. Oecologia 2011, 165, 79-88. [CrossRef]

11. Kimirei, I.A.; Nagelkerken, I.; Trommelen, M.; Blankers, P.; van Hoytema, N.; Hoeijmakers, D.; Huijbers, C.M.; Mgaya, Y.D.; Rypel, A.L. What drives ontogenetic niche shifts of fishes in coral reef ecosystems? Ecosystems 2013, 16, 783-796. [CrossRef]

12. Dahlgren, C.P.; Eggleston, D.B. Ecological processes underlying ontogenetic habitat shifts in a coral reef fish. Ecology 2000, 81, 2227-2240. [CrossRef]

13. Gillanders, B.M.; Able, K.W.; Brown, J.A.; Eggleston, D.B.; Sheridan, P.F. Evidence of connectivity between juvenile and adult habitats for mobile marine fauna: An important component of nurseries. Mar. Ecol. Prog. Ser. 2003, 247, 281-295. [CrossRef]

14. Galaiduk, R.; Radford, B.T.; Saunders, B.J.; Newman, S.J.; Harvey, E.S. Characterizing ontogenetic habitat shifts in marine fishes: Advancing nascent methods for marine spatial management. Ecol. Appl. 2017, 27, 1776-1788. [CrossRef]

15. Bellwood, D.R. Ontogenetic changes in the diet of early post-settlement Scarus species (Pisces: Scaridae). J. Fish Biol. 1988, 33, 213-219. [CrossRef]

16. Clements, K.D.; German, D.P.; Piché, J.; Tribollet, A.; Choat, J.H. Integrating ecological roles and trophic diversification on coral reefs: Multiple lines of evidence identify parrotfishes as microphages. Biol. J. Linn. Soc. 2017, 120, 729-751. [CrossRef]

17. Chen, L.-S. Post-settlement diet shift of Chlorurus sordidus and Scarus schlegeli (Pisces: Scaridae). Zool. Stud. 2002, 41, 47-58.

18. Streit, R.P.; Bellwood, D.R. High prevalence of homing behaviour among juvenile coral-reef fishes and the role of body size. Coral Reefs 2017, 36, 1083-1095. [CrossRef]

19. Welsh, J.Q.; Goatley, C.H.R.R.; Bellwood, D.R. The ontogeny of home ranges: Evidence from coral reef fishes. Proc. R. Soc. B Biol. Sci. 2013, 280, 1-7. [CrossRef]

20. Huijbers, C.M.; Nagelkerken, I.; Layman, C.A. Fish movement from nursery bays to coral reefs: A matter of size? Hydrobiologia 2015, 750, 89-101. [CrossRef]

21. Kimirei, I.A.; Nagelkerken, I.; Griffioen, B.; Wagner, C.; Mgaya, Y.D. Ontogenetic habitat use by mangrove/seagrass-associated coral reef fishes shows flexibility in time and space. Estuar. Coast. Shelf Sci. 2011, 92, 47-58. [CrossRef]

22. Van Lier, J.R.; Wilson, S.K.; Depczynski, M.; Wenger, L.N.; Fulton, C.J. Habitat connectivity and complexity underpin fish community structure across a seascape of tropical macroalgae meadows. Landsc. Ecol. 2018, 33, 1287-1300. [CrossRef]

23. Nagelkerken, I.; Bothwell, J.; Nemeth, R.S.; Pitt, J.M.; van der Velde, G. Interlinkage between Caribbean coral reefs and seagrass beds through feeding migrations by grunts (Haemulidae) depends on habitat accessibility. Mar. Ecol. Prog. Ser. 2008, 368, 155-164. [CrossRef]

24. Berkström, C.; Eggertsen, L.; Goodell, W.; Cordeiro, C.A.M.M.M.M.; Lucena, M.B.; Gustafsson, R.; Bandeira, S.; Jiddawi, N.; Ferreira, C.E.L.E.L. Thresholds in seascape connectivity: The spatial arrangement of nursery habitats structure fish communities on nearby reefs. Ecography 2020, 43, 882-896. [CrossRef]

25. Turgeon, K.; Robillard, A.; Grégoire, J.; Duclos, V.; Kramer, D.L. Functional connectivity from a reef fish perspective: Behavioral tactics for moving in a fragmented landscape. Ecology 2010, 91, 3332-3342. [CrossRef] 
26. Hitt, S.; Pittman, S.J.; Nemeth, R.S. Diel movements of fishes linked to benthic seascape structure in a Caribbean coral reef ecosystem. Mar. Ecol. Prog. Ser. 2011, 427, 275-291. [CrossRef]

27. Nagelkerken, I.; Roberts, C.M.; van der Velde, G.; Dorenbosch, M.; van Riel, M.C.; Cocheret de la Morinière, E.; Nienhuis, P.H. How important are mangroves and seagrass beds for coral-reef fish? The nursery hypothesis tested on an island scale. Mar. Ecol. Prog. Ser. 2002, 244, 299-305. [CrossRef]

28. Berkström, C.; Gullström, M.; Lindborg, R.; Mwandya, A.W.; Yahya, S.A.S.; Kautsky, N.; Nyström, M. Exploring 'knowns' and 'unknowns' in tropical seascape connectivity with insights from East African coral reefs. Estuar. Coast. Shelf Sci. 2012, 107, 1-21. [CrossRef]

29. Lugendo, B.R.; Nagelkerken, I.; van der Velde, G.; Mgaya, Y.D. The importance of mangroves, mud and sand flats, and seagrass beds as feeding areas for juvenile fishes in Chwaka Bay, Zanzibar: Gut content and stable isotope analyses. J. Fish Biol. 2006, 69, 1639-1661. [CrossRef]

30. Sambrook, K.; Hoey, A.S.; Andréfouët, S.; Cumming, G.S.; Duce, S.; Bonin, M.C. Beyond the reef: The widespread use of non-reef habitats by coral reef fishes. Fish Fish. 2019, 20, 1-18. [CrossRef]

31. Honda, K.; Uy, W.H.; Baslot, D.I.; Pantallano, A.D.S.; Nakamura, Y.; Nakaoka, M. Diel habitat-use patterns of commercially important fishes in a marine protected area in the Philippines. Aquat. Biol. 2016, 24, 163-174. [CrossRef]

32. Gullström, M.; Berkström, C.; Öhman, M.C.; Bodin, M.; Dahlberg, M. Scale-dependent patterns of variability of a grazing parrotfish (Leptoscarus vaigiensis) in a tropical seagrass-dominated seascape. Mar. Biol. 2011, 158, 1483-1495. [CrossRef]

33. Nakamura, Y.; Horinouchi, M.; Shibuno, T.; Tanaka, Y.; Miyajima, T.; Koike, I.; Kurokura, H.; Sano, M. Evidence of ontogenetic migration from mangroves to coral reefs by black-tail snapper Lutjanus fulvus: Stable isotope approach. Mar. Ecol. Prog. Ser. 2008, 355, 257-266. [CrossRef]

34. Bonaldo, R.M.; Hoey, A.S.; Bellwood, D.R. The Ecosystem Roles of Parrotfishes on Tropical Reefs. Oceanogr. Mar. Biol. Annu. Rev. 2014, 52, 81-132. [CrossRef]

35. Bellwood, D.R.; Hoey, A.S.; Hughes, T.P. Human activity selectively impacts the ecosystem roles of parrotfishes on coral reefs. Proc. R. Soc. B Biol. Sci. 2012, 279, 1621-1629. [CrossRef]

36. Taylor, B.M.; Houk, P.; Russ, G.R.; Choat, J.H. Life histories predict vulnerability to overexploitation in parrotfishes. Coral Reefs 2014, 33, 869-878. [CrossRef]

37. Fulton, C.J.; Abesamis, R.A.; Berkström, C.; Depczynski, M.; Graham, N.A.J.; Holmes, T.H.; Kulbicki, M.; Noble, M.M.; Radford, B.T.; Tano, S.; et al. Form and Function of tropical macroalgal reefs in the Anthropocene. Funct. Ecol. 2019, 33, 989-999. [CrossRef]

38. Igulu, M.M.; Nagelkerken, I.; Dorenbosch, M.; Grol, M.G.G.; Harborne, A.R.; Kimirei, I.A.; Mumby, P.J.; Olds, A.D.; Mgaya, Y.D. Mangrove habitat use by juvenile reef fish: Meta-analysis reveals that tidal regime matters more than biogeographic region. PLoS ONE 2014, 9, e114715. [CrossRef]

39. Dorenbosch, M.; Grol, M.G.G.; Christianen, M.J.A.; Nagelkerken, I.; van Der Velde, G. Indo-Pacific seagrass beds and mangroves contribute to fish density and diversity on adjacent coral reefs. Mar. Ecol. Prog. Ser. 2005, 302, 63-76. [CrossRef]

40. Bellwood, D.R.; Choat, J.H. A description of the juvenile phase colour pattern of 24 parrotfish species (family Scaridae) from the Great Barrier Reef, Australia. Rec. Aust. Mus. 1989, 41, 1-41. [CrossRef]

41. Grober-Dunsmore, R.; Frazer, T.K.; Lindberg, W.J.; Beets, J. Reef fish and habitat relationships in a Caribbean seascape: The importance of reef context. Coral Reefs 2007, 26, 201-216. [CrossRef]

42. Tano, S.; Eggertsen, M.; Wikström, S.A.; Berkström, C.; Buriyo, A.S.; Halling, C. Tropical seaweed beds are important habitats for mobile invertebrate epifauna. Estuar. Coast. Shelf Sci. 2016, 183, 1-12. [CrossRef]

43. Eggertsen, L.; Ferreira, C.E.L.; Fontoura, L.; Kautsky, N.; Gullström, M.; Berkström, C. Seaweed beds support more juvenile reef fish than seagrass beds in a south-western Atlantic tropical seascape. Estuar. Coast. Shelf Sci. 2017, 196, 97-108. [CrossRef]

44. Bradley, M.; Baker, R.; Nagelkerken, I.; Sheaves, M. Context is more important than habitat type in determining use by juvenile fish. Landsc. Ecol. 2019, 34, 427-442. [CrossRef]

45. Feitosa, J.L.L.; Ferreira, B.P. Distribution and feeding patterns of juvenile parrotfish on algal-dominated coral reefs. Mar. Ecol. 2014, 36, 462-474. [CrossRef]

46. Weigt, L.A.; Baldwin, C.C.; Driskell, A.; Smith, D.G.; Ormos, A.; Reyier, E.A. Using DNA barcoding to assess Caribbean reef rish biodiversity: Expanding taxonomic and geographic coverage. PLoS ONE 2012, 7, e41059. [CrossRef] 
47. De Leon, R.O.D.; White, A.T. Mangrove Rehabilitation in the Philippines. In An International Perspective on Wetland Rehabilitation; Streever, W., Ed.; Springer: Dordrecht, The Netherlands, 1999; pp. 37-42, ISBN 978-94-011-4683-8.

48. Ward, R.D.; Zemlak, T.S.; Innes, B.H.; Last, P.R.; Hebert, P.D.N. DNA barcoding Australia's fish species. Philisophical Trans. R. Soc. 2005, 1847-1857. [CrossRef]

49. Costa, F.O.; Landi, M.; Martins, R.; Costa, M.H.; Costa, M.E.; Carneiro, M.; Alves, M.J.; Steinke, D.; Carvalho, G.R. A ranking system for reference libraries of DNA barcodes: Application to marine fish species from Portugal. PLoS ONE 2012, 7, e0035858. [CrossRef]

50. McClure, E.C.; Sievers, K.T.; Abesamis, R.A.; Hoey, A.S.; Alcala, A.C.; Russ, G.R. Higher fish biomass inside than outside marine protected areas despite typhoon impacts in a complex reefscape. Biol. Conserv. 2020, 241, 108354. [CrossRef]

51. Russ, G.R.; Questel, S.L.A.; Rizzari, J.R.; Alcala, A.C. The parrotfish-coral relationship: Refuting the ubiquity of a prevailing paradigm. Mar. Biol. 2015, 162, 2029-2045. [CrossRef]

52. Stockwell, B.; Jadloc, C.R.L.; Abesamis, R.A.; Alcala, A.C.; Russ, G.R. Trophic and benthic responses to no-take marine reserve protection in the Philippines. Mar. Ecol. Prog. Ser. 2009, 389, 1-15. [CrossRef]

53. Siqueira, A.C.; Bellwood, D.R.; Cowman, P.F. The evolution of traits and functions in herbivorous coral reef fishes through space and time. Proc. R. Soc. B Biol. Sci. 2019, 286, 20182672. [CrossRef] [PubMed]

54. Russ, G.R. Distribution and abundance of herbivorous grazing fishes in the central Great Barrier Reef. I. Levels of variability across the entire continental shelf. Mar. Ecol. Prog. Ser. 1984, 20, 23-34. [CrossRef]

55. Russ, G.R. Distribution and abundance of herbivorous grazing fishes in the central Great Barrier Reef. II. Patterns of zonation of mid-shelf and outhershelf reefs. Mar. Ecol. Prog. Ser. 1984, 20, 35-44. [CrossRef]

56. Bellwood, D.R.; Tebbett, S.B.; Bellwood, O.; Mihalitsis, M.; Morais, R.A.; Streit, R.P.; Fulton, C.J. The role of the reef flat in coral reef trophodynamics: Past, present, and future. Ecol. Evol. 2018, 8, 4108-4119. [CrossRef]

57. Dulvy, N.K.; Sadovy, Y.; Reynolds, J.D. Extinction vulnerability in marine populations. Fish Fish. 2003, 4, 25-64. [CrossRef]

58. Lavergne, S.; Thuiller, W.; Molina, J.; Debussche, M. Environmental and human factors influencing rare plant local occurrence, extinction and persistence: A 115-year study in the Mediterranean region. J. Biogeogr. 2005, 32, 799-811. [CrossRef]

59. Hubert, N.; Meyer, C.P.; Bruggemann, H.J.; Guérin, F.; Komeno, R.J.L.; Espiau, B.; Causse, R.; Williams, J.T.; Planes, S. Cryptic diversity in Indo-Pacific coral-reef fishes revealed by DNA-barcoding provides new support to the centre-of-overlap hypothesis. PLoS ONE 2012, 7, e28987. [CrossRef]

60. Hubert, N.; Hanner, R. DNA Barcoding, species delineation and taxonomy: A historical perspective. DNA Barcodes 2015, 3, 44-58. [CrossRef]

61. Cocheret de la Morinière, E.; Pollux, B.J.A.; Nagelkerken, I.; Hemminga, M.A.; Huiskes, A.H.L.; van der Velde, G. Ontogenetic dietary changes of coral reef fishes in the mangrove-seagrass-reef continuum: Stable isotopes and gut-content analysis. Mar. Ecol. Prog. Ser. 2003, 246, 279-289. [CrossRef]

62. Mumby, P.J. Connectivity of reef fish between mangroves and coral reefs: Algorithms for the design of marine reserves at seascape scales at seascape scales. Biol. Conserv. 2006, 215-222. [CrossRef]

63. Olds, A.D.; Albert, S.; Maxwell, P.S.; Pitt, K.A.; Connolly, R.M. Mangrove-reef connectivity promotes the effectiveness of marine reserves across the western Pacific. Glob. Ecol. Biogeogr. 2013, 22, 1040-1049. [CrossRef]

64. Martin, T.S.H.; Olds, A.D.; Pitt, K.A.; Johnston, A.B.; Butler, I.R.; Maxwell, P.S.; Connolly, R.M. Effective protection of fish on inshore coral reefs depends on the scale of mangrove-reef connectivity. Mar. Ecol. Prog. Ser. 2015, 527, 157-165. [CrossRef]

65. Olds, A.D.; Connolly, R.M.; Pitt, K.A.; Maxwell, P.S. Primacy of seascape connectivity effects in structuring coral reef fish assemblages. Mar. Ecol. Prog. Ser. 2012, 462, 191-203. [CrossRef]

66. Olds, A.D.; Connolly, R.M.; Pitt, K.A.; Maxwell, P.S. Habitat connectivity improves reserve performance. Conserv. Lett. 2012, 5, 56-63. [CrossRef]

67. Lugendo, B.R.; Nagelkerken, I.; Kruitwagen, G.; van der Velde, G.; Mgaya, Y.D. Relative importance of mangroves as feeding habitat for juvenile fish: A comparative study on mangrove habitats with different settings. Bull. Mar. Sci. 2007, 80, 497-512.

68. Adams, A.J.; Ebersole, J.P. Use of back-reef and lagoon habitats by coral reef fishes. Mar. Ecol. Prog. Ser. 2002, 228, 213-226. [CrossRef] 
69. Mellin, C.; Kulbicki, M.; Ponton, D. Seasonal and ontogenetic patterns of habitat use in coral reef fish juveniles. Estuar. Coast. Shelf Sci. 2007, 75, 481-491. [CrossRef]

70. Cocheret De La Morinière, E.; Pollux, B.J.A.; Nagelkerken, I.; van der Velde, G. Post-settlement life cycle migration patterns and habitat preference of coral reef fish that use seagrass and mangrove habitats as nurseries. Estuar. Coast. Shelf Sci. 2002, 55, 309-321. [CrossRef]

71. Nagelkerken, I.; Dorenbosch, M.; Verberk, W.C.E.P.; De Morinière, E.C.; van der Velde, G.; Cocheret de la Morinière, E.; van der Velde, G. Importance of shallow-water biotopes of a Caribbean bay for juvenile coral reef fishes: Patterns in biotope association, community structure and spatial distribution. Mar. Ecol. Prog. Ser. 2000, 202, 175-192. [CrossRef]

72. Fong, C.R.; Chancellor, K.S.; Renzi, J.J.; Robinson, D.R.; Barber, P.H.; Habtes, S.Y.; Fong, P. Epibionts on Turbinaria ornata, a secondary foundational macroalga on coral reefs, provide diverse trophic support to fishes. Mar. Environ. Res. 2018, 141, 39-43. [CrossRef]

73. Johnson, G.B.; Taylor, B.M.; Robbins, W.D.; Franklin, E.C.; Toonen, R.; Bowen, B.; Choat, J.H. Diversity and Structure of Parrotfish Assemblages across the Northern Great Barrier Reef. Diversity 2019, 11, 14. [CrossRef]

74. Welsh, J.Q.; Bellwood, D.R. How far do schools of roving herbivores rove? A case study using Scarus rivulatus. Coral Reefs 2012, 31, 991-1003. [CrossRef]

75. Tolimieri, N. The relationship among microhabitat characteristics, recruitment and adult abundance in the stoplight parrotfish, Sparisoma Viride, at three spatial scales. Bull. Mar. Sci. 1998, 62, 253-268.

76. Sale, P.F.; Danilowicz, B.S.; Doherty, P.J.; Williams, D.M.B. The relation of microhabitat to variation in recruitment of young-of-year coral reef fishes. Bull. Mar. Sci. 2005, 76, 123-142.

77. Williams, D.M. Dynamics of the Pomacentrid community on small patch reefs in One Tree lagoon (Great Barrier Reef). Bull. Mar. Sci. 1980, 30, 159-170.

78. Taylor, B.M.; Lindfield, S.J.; Choat, J.H. Hierarchical and scale-dependent effects of fishing pressure and environment on the structure and size distribution of parrotfish communities. Ecography 2015, 38, 520-530. [CrossRef]

79. Abesamis, R.A.; Saenz-Agudelo, P.; Berumen, M.L.; Bode, M.; Jadloc, C.R.L.; Solera, L.A.; Villanoy, C.L.; Bernardo, L.P.C.; Alcala, A.C.; Russ, G.R. Reef-fish larval dispersal patterns validate no-take marine reserve network connectivity that links human communities. Coral Reefs 2017, 1-11. [CrossRef]

80. Taylor, B.M.; Choat, J.H. Comparative demography of commercially important parrotfish species from Micronesia. J. Fish Biol. 2014, 84, 383-402. [CrossRef]

81. Lou, D.C. Age Specific Patterns of Growth and Reproduction in Tropical Herbivorous Fishes. Ph.D. Thesis, James Cook University, Douglas, Australia, 1992.

82. Nicholson, G.M.; Clements, K.D. Resolving resource partitioning in parrotfishes (Scarini) using microhistology of feeding substrata. Coral Reefs 2020, 39. [CrossRef]

83. Bonaldo, R.M.; Bellwood, D.R. Size-dependent variation in the functional role of the parrotfish Scarus rivulatus on the Great Barrier Reef, Australia. Mar. Ecol. Prog. Ser. 2008, 360, 237-244. [CrossRef]

84. Davis, K.; Carlson, P.M.; Lowe, C.G.; Warner, R.R.; Caselle, J.E. Parrotfish movement patterns vary with spatiotemporal scale. Mar. Ecol. Prog. Ser. 2017, 577, 149-164. [CrossRef]

85. Huijbers, C.M.; Nagelkerken, I.; Debrot, A.O.; Jongejans, E. Geographic coupling of juvenile and adult habitat shapes spatial population dynamics of a coral reef fish. Ecology 2013, 94, 1859-1870. [CrossRef]

86. Moffitt, E.A.; Botsford, L.W.; Kaplan, D.M.; O'Farrell, M.R. Marine reserve networks for species that move within a home range. Ecol. Appl. 2009, 19, 1835-1847. [CrossRef]

87. Grüss, A.; Kaplan, D.M.; Guénette, S.; Roberts, C.M.; Botsford, L.W. Consequences of adult and juvenile movement for marine protected areas. Biol. Conserv. 2011, 144, 692-702. [CrossRef]

88. Weeks, R. Incorporating seascape connectivity in conservation prioritisation. PLoS ONE 2017, 12, e0182396. [CrossRef] [PubMed]

(C) 2020 by the authors. Licensee MDPI, Basel, Switzerland. This article is an open access article distributed under the terms and conditions of the Creative Commons Attribution (CC BY) license (http://creativecommons.org/licenses/by/4.0/). 